\title{
RISK ANALYSIS IN THE LOGISTICS COMPANY FOR DISTRIBUTION OF PHARMACEUTICALS
}

\author{
Lucie Chromcová
}

\begin{abstract}
The paper is focused on risk analysis in the logistics company, which distributed pharmaceuticals. Firstly, basic concepts in the field of logistics are discussed, and the approach to the correct distribution of medicines is emphasized. Secondly, a specific logistics company distributing medicines is also presented, including its transportation process. Additionally, failure mode and effect analysis (FMEA) as a risk analysis method is applied to the process. Based on the results of the analysis, recommendations are made to reduce the most severe risks in distribution pharmaceutics.
\end{abstract}

Keywords: risk, risk analysis, logistics company, distribution, pharmaceuticals

\section{INTRODUCTION}

In today's exciting times, humanity had to adapt to the rapid pressure on distribution time and logistics in general. The actual distribution of medicines is subject to demanding availability of all pharmaceuticals that people use. The cornerstone for medication distribution is the right fleet and the proper selection of a carrier to transport pharmaceuticals to pharmacies. For medicines to help the end customer, a specific transport system that does not violate storage and transport conditions need to be applied. With the increasing number of types of pharmaceuticals, the probability that something goes incorrect and the medicines will not reach the customer in the end, and further when applied in case of non-compliance with the transport conditions, has increased. They will not have the desired effect. We will try to identify, analyse, and set up possible measures to eliminate or mitigate the consequences of any situation that may hurt the medicine delivery logistics chain or on the safety of the drugs themselves.

Modern times have brought centralization and outsourcing to pharmacy logistics. In practice, this means that services or processes are set aside outside the organization. Own warehouses are not carried, but stocks in contract warehouses are used. Therefore, it is more efficient to control the assortment and better ability to manage all services at the central level, thus changing the quality for customers. Unfortunately, this also has its drawbacks; there may be insufficient flexibility. The outsourced company is more controllable. Besides, they hold their know-how and resources for their customers, which do not have to be dealt with by the outsourcing client. (Novák, 2005; Novák, 2011; Rushton, Croucher \& Baker, 2014)

Due to changes in legislative rules, the stricter conditions for medication handling are a new trend. Direct distribution in the Czech Republic - direct to the pharmacy (DTP) or direct to the hospital (DTH) - is the common widely used in the Czech Republic. How does such direct drug distribution work? Distributors do not care about anything, because manufacturers themselves watch for parallel trade and get their distribution authorization. In practice, this means that the traditional distribution network is not used, but drugs are supplied directly to pharmacies, and the manufacturer takes over the activities of the distributor. (Kluska, 2016; Weberová, 2013)

The aim of this paper is to map and analyse processes in the logistics chain of medication transport and to create proposals for reducing or eliminating risks in a logistics company for drug distribution. To propose options for improving the distribution process itself. It is essential 
to imagine concepts from the fields of logistics, distribution in general, medication distribution, fleet determination for pharmaceuticals alone, and approaches.

\section{METHODOLOGY}

The FMEA method was chosen for the analysis of the pharmaceutical distribution process for the Olomouc Transhipment Station. The emerging processes were used to analyse risks and, based on frequencies, to propose risks or minimize them. For the various severe risks unacceptable by the dock owner, such proposals will be accompanied by a degree of risk reduction, which could be applied in the future to create a better functioning risk reduction system. Failure Mode and Effects Analysis (FMEA) was used in this paper. It is an analytical method that ensures prevention and possible solution to potential problems in the system of origin of the whole process. Risk analysis is part of the study. The application of the FMEA method is performed as an examination of functions or changes, assuming the risk of possible failure.

By introducing the results of the analysis into the evaluated process, increased attention will be paid to each subsystem, element separately. Each item valued as critical is then assessed according to our priorities, e.g. impact on the whole system of processes. FMEA is applied as a prevention against the problem itself, so its timely application to the process is essential. Thanks to this analysis, we could prevent a possible critical situation before it occurs, at a lower cost than after its occurrence. Properly applied measures are introduced as a reduction of the probability of deviation in the whole process. (Petrašová, 2008; Procházková, 2011)

When creating an FMEA design or the FMEA process itself, we will use a standard problemsolving approach. Comprehensive analysis system consists of: concept of basics for analysis, subject of analysis, end customers (for whom the analysis is intended), identification of functions and continuity of elements, consequences of failures and defining emerging failures, enumeration of failure management tools (causes of crashes) or measures and suggestions for risk elimination. (Petrašová, 2008; Procházková, 2011)

\section{CURRENT STATE}

Due to the increased number of pharmaceuticals, a large number of errors and disturbances have been seen that affect the operation of the Transhipment Station. Although the Transhipment Centre was established about ten years ago, there was never any analysis applied, so we decided to set up a risk analysis for failures and serviceability. It would be desirable for the analysis to comply with the transport and general conditions for the distribution of drugs and to comply with all applicable standards. Therefore, the work aims to create the correct FMEA analysis, propose risk measures and recommendations in control, deadline, and possible mitigation of risk impact. Then interpret the results to the owner of the Transhipment.

PHOENIX Company has been a leader in the distribution market in the Czech Republic for several years. It has been a member of the multinational PHOENIX Group, one of Europe's top drug distribution companies since 1994. The Group operates in 26 European countries, with more than a thousand business partners (pharmacies, hospitals, and pharmaceutical manufacturing companies) happy with its services and time flexibility. Over the long years of its operations in the Czech Republic, Phoenix has built a base of six shopping centres that create a reliable network for the storage and subsequent distribution of pharmaceuticals in Bohemia and Moravia. (PHOENIX, 2017) 


\section{RESULTS}

The FMEA method was chosen for the risk analysis in the pharmaceutical distribution company. Based on process and error observations, the following criteria were analysed and evaluated.

Tab. 1 - FMEA. Source: own research

\begin{tabular}{|c|c|c|}
\hline $\begin{array}{l}\text { The meaning of the } \\
\text { consequences of error }\end{array}$ & Level of meaning & Classification \\
\hline Extremely serious & $\begin{array}{l}\text { the significance of the error is extremely high; the failure endangers the } \\
\text { safety and conditions for medicine transport }\end{array}$ & $9-10$ \\
\hline Significant & $\begin{array}{l}\text { dissatisfaction is tremendous and is caused by a wrong action in the logistics } \\
\text { chain, the high probability that the error will occur }\end{array}$ & $7-8$ \\
\hline Moderate & the significance of the error will create discontent at the customer & $4-6$ \\
\hline Insignificant & the significance of the error may be of concern to the customer & $2-3$ \\
\hline Hardly noticeable & $\begin{array}{l}\text { it is unlikely that the error will affect the customer (the customer will not } \\
\text { notice the error) }\end{array}$ & 1 \\
\hline
\end{tabular}

The effect of the consequences of errors occurring in individual processes was analysed according to the importance of the failure per customer or the entire logistics chain. It was agreed with the owner of the Transhipment Centre that the significance limits would also be included in the medium-term consequences of errors depending on the remaining criteria.

Tab. 2 - FMEA. Source: own research

\begin{tabular}{|c|c|c|c|}
\hline $\begin{array}{l}\text { The meaning of the } \\
\text { consequences of error }\end{array}$ & Level of meaning & Classification & Failure rate \\
\hline \multirow{2}{*}{ Extremely serious } & \multirow{2}{*}{ failure cannot be detected and secured } & 10 & \multirow{2}{*}{450 from 1000} \\
\hline & & 9 & \\
\hline \multirow{3}{*}{ High } & \multirow{3}{*}{ check performed, failure occur frequently } & 8 & \multirow{3}{*}{350 from 1000} \\
\hline & & 7 & \\
\hline & & 6 & \\
\hline \multirow{2}{*}{ Small } & \multirow{2}{*}{ check performed, failure arise on a smaller scale } & 5 & \multirow{2}{*}{290 from 1000} \\
\hline & & 4 & \\
\hline \multirow{2}{*}{ Slight } & \multirow{2}{*}{ only minor failures are considered } & 3 & \multirow{2}{*}{200 from 1000} \\
\hline & & 2 & \\
\hline Unlikely & we can almost eliminate failure & 1 & 150 from 1000 \\
\hline
\end{tabular}

The occurrence of the consequences of errors was analysed for less than two years. These errors were recorded in frequency. Based on this data, a network of controls for early detection was established.

Tab. 3 - FMEA. Source: own research

\begin{tabular}{|c|c|c|}
\hline $\begin{array}{c}\text { Probability of failure } \\
\text { detection }\end{array}$ & Probability level & Classification \\
\hline High & process security methods cannot be provided & $\mathbf{1 0}$ \\
\hline Moderate & Process security methods could barely detect a potential failure & $\mathbf{8}-\mathbf{9}$ \\
\hline Small & Process security methods have a probability of detection & $\mathbf{5 - 7}$ \\
\hline Very small & Process security methods could detect a possible failure & $\mathbf{2 - 4}$ \\
\hline Unlikely & $\begin{array}{c}\text { methods of securing the detection process most likely a possible failure (the } \\
\text { process detects the failure automatically) }\end{array}$ & $\mathbf{1}$ \\
\hline
\end{tabular}

The probability of error detection ensures early detection of the error and its securing in the bud of the whole process.

Tab. 4 - Risk calculation. Source: own research

$\begin{array}{ccc} & \text { Risk calculation } & \\ \text { Small risk } & <1 ; 200> & \text { Green } \\ \text { Medium risk } & <201 ; 395> & \text { Yellow } \\ \text { High risk } & <396 ; 900> & \text { Red }\end{array}$




\section{PROPOSED MEASURES AND RECOMMENDATIONS}

Measures and recommendations should reduce the impact of risks or eliminate failures. When carrying out the FMEA, each process was individually designed to reduce the probability of a mistake. The proposed measures and recommendations will always be specified for the process steps in the following table. The most critical failures will be selected.

Tab. 5 - FMEA. Source: own research

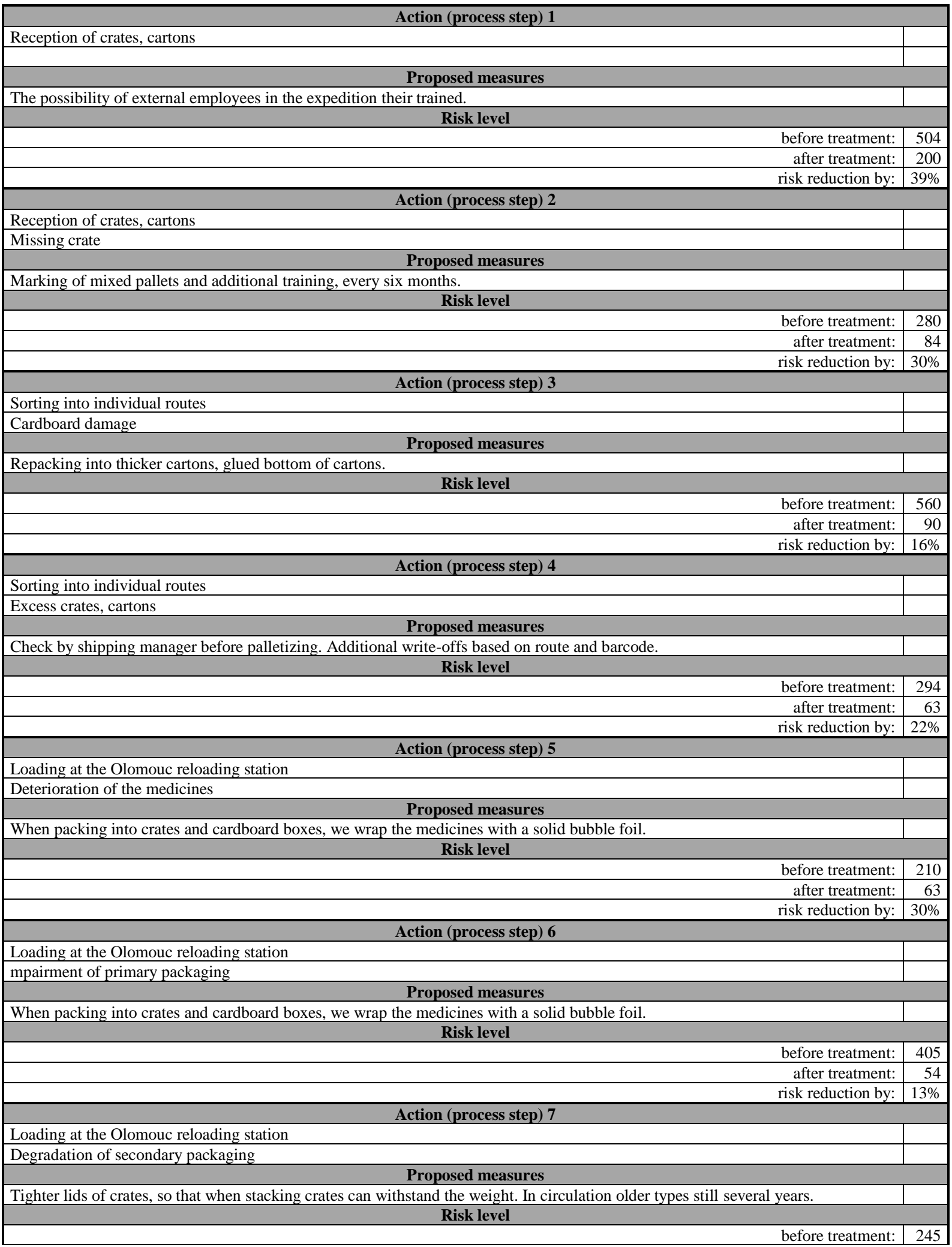


Loading at the Olomouc reloading station

Action (process step) 8

Loading multiple boxes, cartons

In case of missing box / carton on another route check all loaded vehicles at the Transhipment Station before leaving for unloading

Proposed measures

\section{to the pharmacy.}

before treatment: 210

Action (process step) 9

Unloading at the pharmacy

Broken boxes, cardboard boxes

Proposed measures
Tighter lids of crates, so that when stacking crates can withstand the weight. In circulation older types still several years.

\section{Risk level}

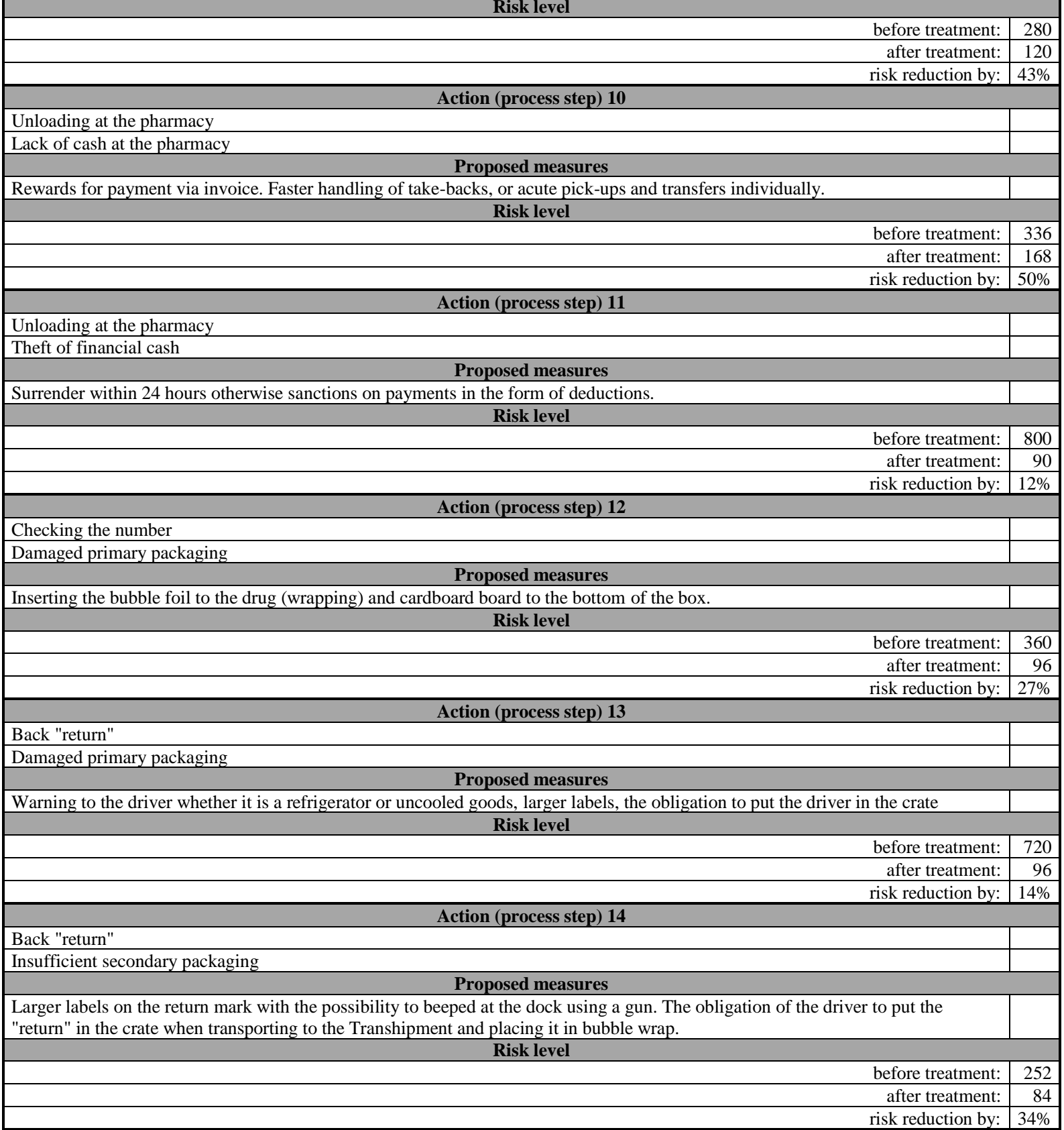




\section{CONCLUSION}

The paper dealt with the issue of risk analysis at the Transhipment for Pharmaceuticals. The aim was to create comprehensive proposals for reducing or eliminating risks in the logistics chain process at a pharmaceutical distribution company. The reader was acquainted with basic concepts and the procedure for resolving emerging failures. It was essential to introduce the pharma wholesale company Phoenix, a.s. and its transport procedure with haulers at the Olomouc transshipment station. FMEA analysis was used in the theoretical part. By mapping the risks and processes of the Medical Stations, the individual risk measures for the steps have made suggestions to eliminate or reduce critical risks or risks that might begin to emerge to a greater extent in the future. Based on the results of the FMEA analysis, the objective of the work has been fulfilled, and the implementation of proposals in practice can lead to an overall reduction of the total process failure by up to half.

\section{References}

Kluska, V. (2016). Změní legislativní úprava reexportů lékový trh? Retrieved from https://zdravi.euro.cz/clanek/zmeni-legislativni-uprava-reexportu-lekovy-trh-481593

Novák, R. (2011). Přepravní, zasilatelské a logistické služby. Praha: Wolters Kluwer.

Novák, R. (2005). Nákladní doprava a zasílatelství. Praha: ASPI.

Petrašová, I. (2008). Analýza možných způsobů a důsledků poruch (FMEA): Referenční príručka. Praha: Česká společnost pro jakost.

PHOENIX. (2017). Profil společnosti. Retrieved from http://www.phoenix.cz/o-nas/profilspolecnosti/

Procházková, D. (2011). Analýza a řizení rizik. Praha: ČVUT.

Rushton, A., Croucher, P. \& Baker, P. (2014). The Handbook of Logistics and Distribution Management. London: Kogan.

Weberová, A. (2013). Logistika léků: Ortodoxní pravidla. Retrieved from https://www.systemylogistiky.cz/2013/05/06/logistika-leku-ortodoxni-pravidla/

\section{Contact information}

\section{Lucie Chromcová}

Tomas Bata University in Zlín, Faculty of Logistics and Crisis Management

Studentské nám. 1532, 68601, Uherské Hradiště, Czech Republic

E-mail:1_chromcova@utb.cz

ORCID: 0000-0001-7218-7394

doi: 10.7441/dokbat.2019.042 